\title{
Anisakid larva parasitizing Plagioscion squamosissimus in Marajó Bay and Tapajós River, state of Pará, Brazil
}

\author{
Larva de anisaquídeo parasitando Plagioscion squamosissimus na Baía de Marajó e no Rio Tapajós, \\ estado do Pará, Brasil
}

\author{
Gabrielle Fontenelle ${ }^{1,2}$; Marcelo Knoff ${ }^{3 *}$; Nilza Nunes Felizardo ${ }^{2}$; Eduardo José Lopes Torres ${ }^{4}$; \\ Edilson Rodrigues Matos ${ }^{5}$; Delir Corrêa Gomes ${ }^{3}$; Sérgio Carmona de São Clemente ${ }^{2}$
}

\author{
${ }^{1}$ Programa de Pós-graduaçáo em Higiene Veterinária e Processamento Tecnológico de Produtos de Origem Animal, \\ Universidade Federal Fluminense - UFF, Niterói, RJ, Brasil \\ ${ }^{2}$ Laboratório de Inspeção e Tecnologia de Pescado, Universidade Federal Fluminense - UFF, Niterói, RJ, Brasil \\ ${ }^{3}$ Laboratório de Helmintos Parasitos de Vertebrados, Instituto Oswaldo Cruz, Fundação Oswaldo Cruz - FIOCRUZ, \\ Rio de Janeiro, RJ, Brasil \\ ${ }^{4}$ Laboratório de Helmintologia Romero Lascasas Porto, Faculdade de Ciências Médicas, Universidade do Estado do Rio de Janeiro - \\ UERJ, Rio de Janeiro, RJ, Brasil \\ ${ }^{5}$ Laboratório de Pesquisa Carlos Azevedo, Instituto de Saúde e Produção Animal, Universidade Federal Rural da Amazônia - UFRA, \\ Belém, PA, Brasil
}

Received March 2, 2016

Accepted April 18, 2016

\begin{abstract}
In November 2014 and May 2015, a total of 44 specimens of the South American silver croaker Plagioscion squamosissimus were collected: 30 in Marajó Bay and 14 in the Tapajós River, state of Pará, Brazil. The aim was to investigate the presence of anisakid nematodes and determine their parasitism indices and sites of infection, because of their importance regarding health inspection. Sixty-nine Anisakis sp. larvae were found; among them, 16 larvae in seven fish collected in Marajó Bay and 53 larvae in four fish in the Tapajós River. The parasitism indices of the nematodes collected from the fish in Marajó Bay comprised prevalence (P) of 23\%, mean infection intensity (MI) of 2.28, mean abundance (MA) of 0.53 , range of infection (RI) of 1-4, and infection site (IS) in the mesentery. The fish from the Tapajós River showed $\mathrm{P}=28 \%$, $\mathrm{MI}=13.2, \mathrm{MA}=3.8, \mathrm{RI}=1-22$, and $\mathrm{IS}=$ mesentery and intestine. To assist in taxonomic identification, images of the specimens obtained through optical microscopy with Nomarski's interferential contrast system and scanning electron microscopy were used. This is the first record of Anisakis sp. parasitizing P. squamosissimus.
\end{abstract}

Keywords: Sciaenidae, freshwater fish, Anisakidae, Northern Brazil.

\section{Resumo}

Em novembro de 2014 e maio de 2015, foi coletado um total de 44 espécimes de pescada branca, Plagioscion squamosissimus, sendo 30 na Baía de Marajó e 14 no Rio Tapajós, Estado do Pará, Brasil, com o objetivo de pesquisar a presença de nematoides anisaquideos e fornecer os índices parasitários, assim como os sítios de infecção, devido a sua importância na inspeção sanitária. Encontrou-se um total de 69 larvas de Anisakis sp., sendo 16 em 7 peixes coletados da Baía de Marajó e 53 larvas em 4 peixes do Rio Tapajós. Os índices parasitários desses nematoides coletados dos peixes da Baía de Marajó apresentaram prevalência (P) de 23\%, intensidade média (IM) de 2,28, abundância média (AM) de 0,53, amplitude de variação da intensidade de infecção (AI) de 1-4 e sítio de infecção (SI) o mesentério; e os do Rio Tapajós $\mathrm{P}=28 \%, \mathrm{IM}=13,2, \mathrm{AM}=3,8, \mathrm{AI}=1-22$ e SI = mesentério e intestino. Para auxiliar na identificação taxonômica foram utilizadas imagens obtidas dos espécimes por microscopia ótica com sistema de contraste interferencial de Nomarski e microscopia eletrônica de varredura. Esse é o primeiro registro de Anisakis sp. parasitando P. squamosissimus.

Palavras-chave: Sciaenidae, peixe de água doce, Anisakidae, Norte do Brasil.

\footnotetext{
*Corresponding author: Marcelo Knoff. Laboratório de Helmintos

Parasitos de Vertebrados, Instituto Oswaldo Cruz, Fundação Oswaldo Cruz

- FIOCRUZ, Avenida Brasil, 4365, Manguinhos, CEP 21045-900, Rio de

Janeiro, RJ, Brasil. e-mail: knoffm@ioc.fiocruz.br
} 


\section{Introduction}

Plagioscion squamosissimus (Heckel, 1840) is a sciaenid fish commonly known as the South American silver croaker. It lives in benthopelagic environments and, during its life cycle, it migrates from freshwater to brackish water. In the juvenile stage, it feeds on shellfish larvae and aquatic insects; and in the adult stage, it feeds on copepods. In South America, it occurs in many countries basins: Amazon, Orinoco, Paraná, Paraguay, and São Francisco River basins and rivers of Guianas (CASATTI, 2003). This fish is considered to be of high commercial importance in northern Brazil, i.e. in the lower Amazon region, including the city of Santarém, state of Pará, and on the coast of the state of Amapá and in indentations of the states of Maranhão and Pará (FERREIRA et al., 1998; CAMARGO \& ISSAC, 2001; MELO et al., 2014).

In Brazil, there are many records of helminth parasites in this host, including anisakid species (MARTINS et al., 2000; TAVARES et al., 2007; EIRAS et al., 2010; DIAS et al., 2011; MELO et al., 2014; RODRIGUES et al., 2015).

Species belonging to the genus Anisakis (Dujardin, 1845) have mostly been found in many species of Brazilian marine fish (KNOFF et al., 2013; FONTENELLE et al., 2013). There is also one record in a fish species that inhabits freshwater and brackish water, $P$. squamosissimus, in the municipality of Colares, state of Pará (RODRIGUES et al., 2015).

The intermediate hosts of anisakids include crustaceans, cephalopods and fish, and their definitive hosts are ichthyophagous marine mammals (KLIMPEL \& PALM, 2011). In Brazil, species of Anisakis have been recorded in marine mammals by many authors (SANTOS et al., 1996; ANDRADE et al., 1997; ZERBINI \& SANTOS, 1997; SANTOS \& LODI, 1998; MOTTA et al., 2008; IÑIGUEZ et al., 2009, 2011; DI AZEVEDO et al., 2015). Humans can become infected by ingesting some species of nematode larvae of Anisakidae that are present in fishery products such as raw, undercooked, smoked or insufficiently salted fish. Species of Anisakis are capable of causing diseases such as anisakiasis (KLIMPEL \& PALM, 2011).

A single case of anisakiasis has been reported in Brazil, in a man in the state of Mato Grosso, with the larvae located in the mucosa of the duodenum (CRUZ et al., 2010).

This study aimed to investigate the presence of larval stages of anisakid nematodes in P. squamosissimus collected in Marajó Bay, in the municipality of Belém, and in the Tapajós River, municipality of Santarém, both in the state of Pará, Brazil, and to determine their parasitism indices and infection sites.

\section{Materials and Methods}

A total of 44 specimens of the South American silver croaker, P. squamosissimus (Heckel, 1840) were purchased from professional fishermen in the state of Pará, Brazil. Among these, 30 silver croaker (measuring 30-32 cm in total length) had been caught in Marajó Bay, municipality of Belém (latitude $1^{\circ} 0$ ' 2" S, longitude $50^{\circ} 12^{\prime} 28^{\prime \prime} \mathrm{W}$ ) in November 2014; and 14 (measuring 23-29.5 cm in total length) in the Tapajós River, municipality of Santarém (latitude $02^{\circ} 24^{\prime} 54.6^{\prime}$ S, longitude $54^{\circ} 44^{\prime} 18.6^{\prime \prime} \mathrm{W}$ ) in May
2015. The fish were transported in isothermal boxes with ice to the Carlos Azevedo Research Laboratory, Institute of Animal Health and Production, Federal Rural University of the Amazon Region, Belém, state of Pará, Brazil. The fish were identified in accordance with Casatti (2003).

After necropsying and filleting the fish, nematode larvae were found and placed in Petri dishes with $0.65 \% \mathrm{NaCl}$ solution. The specimens were then fixed in alcohol, formalin, and acetic acid (AFA) $\left(60^{\circ} \mathrm{C}\right)$, preserved in a solution of $70^{\circ} \mathrm{GL}$ ethanol plus 5\% glycerin and clarified with Amman's lactophenol, as described by Knoff \& Gomes (2012).

The taxonomic classification of nematodes was made in accordance with Fagerholm (1991). The larvae were identified as described by Felizardo et al. (2009) and Fontenelle et al. (2013).

The samples were analyzed by bright-field microscopy using Nomarski's differential interference contrast (DIC) apparatus. Images were obtained using a Canon digital camera (Power Shot A640) coupled to a Zeiss Axiophot microscope. For topographic characterization of the cuticular surface, four third-stage larvae of Anisakis sp. were analyzed using a scanning electron microscope (SEM). The material was processed as described by Lopes Torres et al. (2013). The samples fixed in 70\% ethanol were dehydrated in an ethanol series $\left(70^{\circ}\right.$ and $\left.100^{\circ} \mathrm{GL}\right)$, with $\mathrm{CO}_{2}$ critical point drying, coated in gold, examined and photographed using a SEM (JEOL SM-25 SII), under $15 \mathrm{kV}$ acceleration voltage.

Morphometric analyses were performed using an Olympus BX41 microscope. Measurements were shown in millimeters $(\mathrm{mm})$ with the averages in parentheses, unless otherwise indicated. The parasitism indices of prevalence, mean intensity and mean abundance were obtained as described by Bush et al. (1997).

Representative specimens of Anisakis sp. were deposited in the Helminthological Collection of the Oswaldo Cruz Institute (CHIOC), Rio de Janeiro, state of Rio de Janeiro, Brazil.

\section{Results}

Among the 44 specimens of P. squamosissimus analyzed, 11 were parasitized with 69 live third-stage larvae (L3) of Anisakis sp.: seven fish from Marajó Bay containing $16 \mathrm{~L}_{3}$; and four fish from the Tapajós River containing 53 L3. Table 1 shows the prevalence

Table 1. Prevalence (P), mean intensity (MI), mean abundance (MA), range of infection (RI), infection site (IS) and CHIOC deposit number of Anisakis sp. third-stage larvae collected from Plagioscion squamosissimus caught in Marajó Bay, municipality of Belém, in November 2014; and in the Tapajós River, municipality of Santarém, in May 2015; both locations in the state of Pará, Brazil.

\begin{tabular}{|c|c|c|c|c|c|c|}
\hline \multirow{2}{*}{ Location } & \multicolumn{6}{|c|}{ Anisakis sp. } \\
\hline & P (\%) & MI & MA & RI & IS & CHIOC \\
\hline $\begin{array}{l}\text { Marajó } \\
\text { Bay }\end{array}$ & 23.33 & $2.29 \pm 1.03$ & $0.53 \pm 1.09$ & $1-4$ & M & 36765 \\
\hline $\begin{array}{l}\text { Tapajós } \\
\text { River }\end{array}$ & 28.57 & $13.25 \pm 7.76$ & $3.79 \pm 7.28$ & $1-22$ & M, I & 36764 \\
\hline
\end{tabular}

$\mathrm{M}=$ mesentery; $\mathrm{I}=$ intestine; $\mathrm{CHIOC}=$ Helminthological Collection of the Oswaldo Cruz Institute. 
(P), mean infection intensity (MI), range of infection intensity (RI), mean abundance (MA), infection site (IS) and deposition number at CHIOC.

Anisakidae Railliet \& Henry, 1912

Anisakis Dujardin, 1845

Anisakis sp. (Figures 1, 2)

The main features observed in the third-stage larvae were as follows: (1) anterior extremity with one dorsal and two poorly developed ventrolateral lips; (2) six cephalic papillae, one pair in the dorsal lip and one pair in each ventrolateral lip; (3) boring tooth below the oral aperture, between the two ventrolateral lips; (4) excretory pore opening beneath the boring tooth; (5) inconspicuous nerve ring; (6) ventriculus length greater than its width; (7) ventricular appendix and intestinal cecum absent; (8) two nearly spherical rectal glands; and (9) conical tail and mucron present.

Measurements were made on fourty Anisakis sp. $\mathrm{L}_{3}$ collected from P. squamosissimus: body length 12.1-13.4 (12.9); body width 0.27-0.36 (0.33); esophagus length 0.98-1.40 (1.21); ventriculus length $0.36-0.68(0.48)$; ventriculus width $0.12-0.20(0.15)$; tail length $0.07-0.10$ (0.08); and mucron length 0.03 (0.02-0.04).

\section{Discussion and Conclusion}

Plagioscion squamosissimus is a species of freshwater fish that also habits brackish water environments (CASATTI, 2003). In the present study, it was collected from two municipalities, Belém and Santarém, in the Amazon hydrographic basin, which are affected by direct influence from Atlantic ocean waters. The presence of larval stages of Anisakis sp. parasitizing P. squamosissimus confirms this environmental intersection of salinities, given the hosts used by the four larval stages within the life cycle of Anisakis species, within the eggs (L1-L3) and subsequently in intermediate and paratenic hosts (L3), and as pre-adults (L4) and adults in the cetacean final hosts (KLIMPEL \& PALM, 2011). The present study expands the occurrence of Anisakis sp. in P. squamosissimus to two additional municipalities in the state of Pará (RODRIGUES et al., 2015).

The larvae of Anisakis sp. collected in the present study were morphologically similar to specimens of $A$. simplex (Rudolphi, 1809) and Anisakis sp. that were recorded in Paralichthys isosceles Jordan, 1890, and Cynoscion guatucupa (Cuvier, 1830), collected on the coast of the state of Rio de Janeiro by Felizardo et al. (2009) and Fontenelle et al. (2013), respectively. However, morphometrically, they showed smaller body size than the ones collected by Felizardo et al. (2009) (15.60 length x 0.36 width)

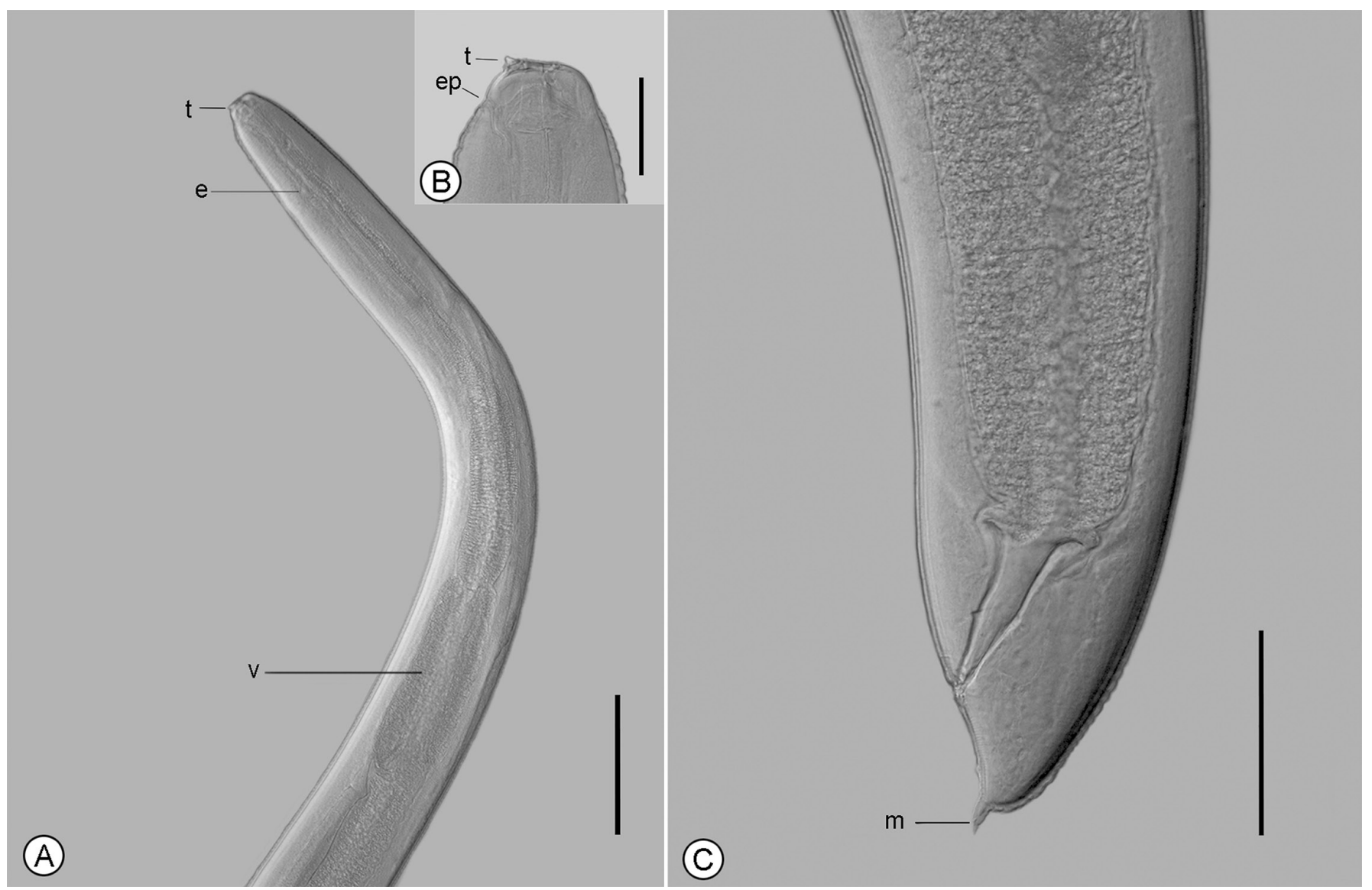

Figure 1. Anisakis sp. (L3) from Plagioscion squamosissimus observed by differential interference contrast, in lateral view. A - anterior portion showing boring tooth $(\mathrm{t})$, esophagus (e) and ventricle (v). B - Detail of boring tooth (t) and excretory pore (ep). C - Posterior portion showing tail with terminal mucron (m). Scale bars: $\mathbf{A}=200 \mu \mathrm{m}, \mathbf{B}=50 \mu \mathrm{m}$ and $\mathbf{C}=100 \mu \mathrm{m}$. 


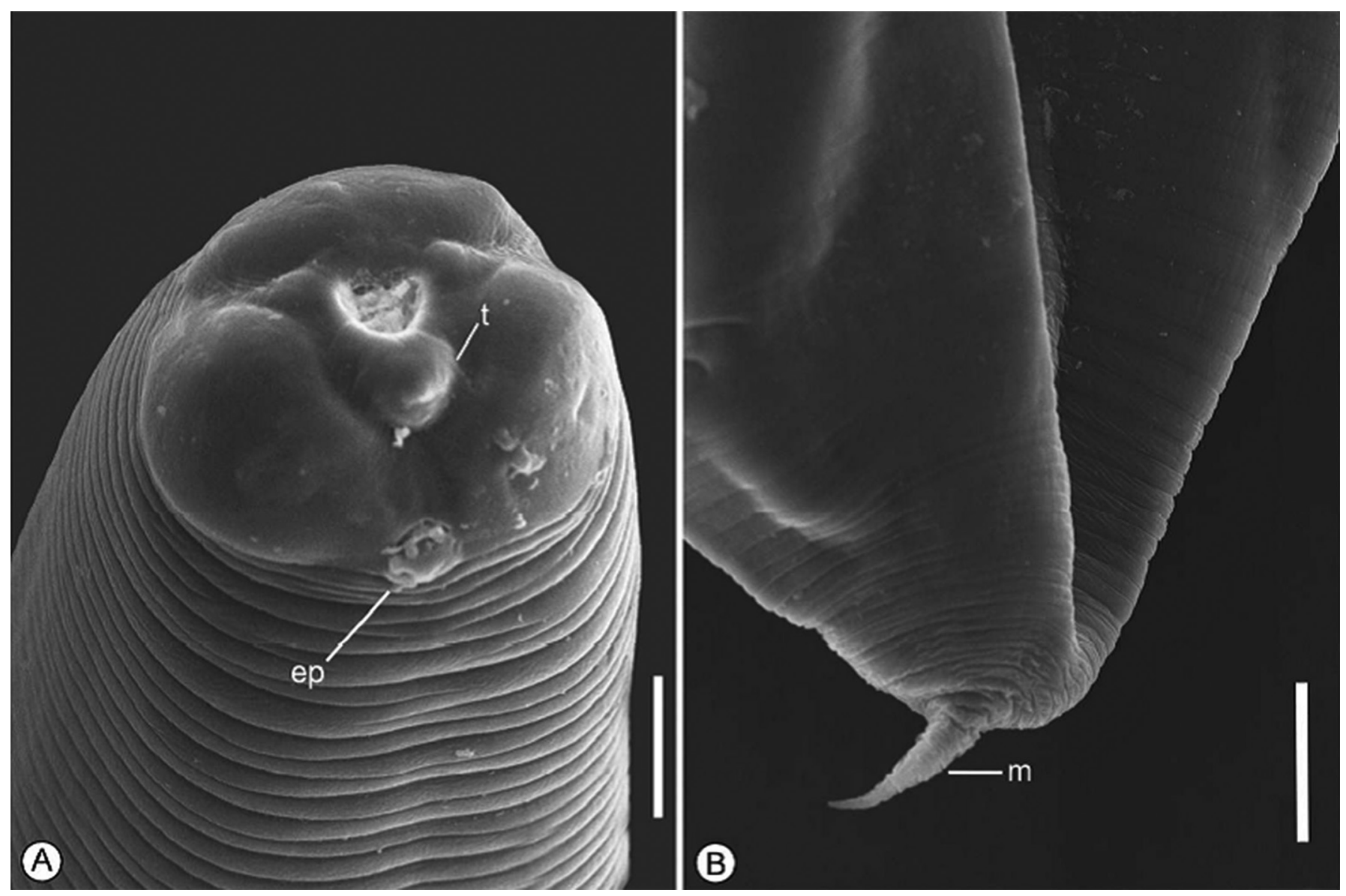

Figure 2. Anisakis sp. (L3) from Plagioscion squamosissimus observed by scanning electron microscopy, in ventrolateral view. A - anterior portion showing boring tooth $(\mathrm{t})$ and excretory pore (ep). Bar: B - posterior portion showing striated tail with terminal mucron (m). Scale bars: $\mathbf{A}=20 \mu \mathrm{m}$ and $\mathbf{B}=10 \mu \mathrm{m}$.

and Fontenelle et al. (2013) (22.33 length x 0.44 width). These differences in the lengths and widths of nematode larvae between the observations of Felizardo et al. (2009), Fontenelle et al. (2013) and the present study are possibly related to different hosts or the influences of different ecoregions, given that the specimens examined were purchased in different biogeographic areas, i.e. temperate South America (state of Rio de Janeiro) and tropical Atlantic (state of Pará) (SPALDING et al., 2007).

Melo et al. (2014) reported that anisakid larvae (without generic identification) were present as parasites in $100 \%$ of the P. squamosissimus specimens collected from the estuary of the Guamá River and the neighboring Guajará Bay, adjacent to the municipality of Belém, state of Pará. The prevalence in their study was around $75 \%$ higher than what was found in the present study for Anisakis sp. Rodrigues et al. (2015) recorded that the prevalence of Anisakis sp. in the same host was slightly lower (10\%) than that of the present study. In the present study, the infection sites were the mesentery and intestine, and these sites have also cited by other authors. Melo et al. (2014) found larvae in the serosa surrounding the internal organs, in which they observed weak inflammatory reaction.

In both previous studies in the state of Pará involving anisakids, there was no indication of nematode specimens in a zoological collection. This made it impossible to determine the morphology and morphometry of their larvae in comparison with those of the present study.

The presence of live larvae parasitizing $P$. squamosissimus specimens caught in Marajó Bay and the Tapajós River, along with high prevalence, enables postmortem migration of these larvae into the musculature. Therefore, attention paid towards consumption of raw fish in exotic dishes needs to be increased, because such consumption can increase the risk of acquiring anisakiasis. It is also important to draw attention to this species, given that it can cause gastrointestinal disorders and allergic reactions even if consumed cooked (AUDICANA \& KENNEDY, 2008).

\section{Acknowledgements}

The authors would like to thank to Mr. Ricardo Baptista Schmidt (Production and Image Processing Service of the Oswaldo Cruz Institute/Fiocruz for processing the figures; and the National Council for Scientific and Technological Development (CNPq) and the Coordination Office for Improvement of Higher Education Personnel (CAPES) for partial financial support. 


\section{References}

Andrade A, Pinedo MC, Pereira J Jr. The gastrointestinal helminths of the Franciscana, Pontoporia blainvillei, in southern Brazil. Annu Rep Int Whal Commn 1997; 47: 669-673.

Audicana MT, Kennedy MW. Anisakis simplex: from obscure infectious worm to inducer of immune hypersensitivity. Clin Microbiol Rev 2008; 21(2): 360-379. http://dx.doi.org/10.1128 /CMR.00012-07.

Bush AO, Lafferty KD, Lotz JM, Shostak AW. Parasitology meets ecology on its own terms: Margolis et al. revisited. J Parasitol 1997; 83(4): 575583. http://dx.doi.org/10.2307/3284227. PMid:9267395.

Camargo M, Issac V. Os peixes estuarinos da regiáo Norte do Brasil: Lista de espécies e considerações sobre sua distribuição geográfica. Bol Mus Paraense Emílio Goeldi. S N Zool 2001; 17(2): 133-157.

Casatti L. Sciaenidae (Drums or croakers). In: Reis RE, Kullander SO, Ferraris CJ Jr. Checklist of the freshwater fishes of South and Central America. Porto Alegre: EDIPUCRS; 2003. p. 599-602.

Cruz AR, Souto PCS, Ferrari CKB, Allegretti SM, Arrais-Silva WW. Endoscopic imaging of the first clinical case of Anisakidosis in Brazil. Sci Parasitol 2010; 11(2): 97-100.

Di Azevedo MIN, Knoff M, Carvalho VL, Mello WN, Torres EJL, Gomes DC, et al. Morphological and genetic identification of Anisakis paggiae (Nematoda: Anisakidae) in dwarf sperm whale Kogia sima (Owen, 1866) from Brazilian waters. Dis Aquat Org 2015; 113(2): 103-111. http:// dx.doi.org/10.3354/dao02831.

Dias LNS, Paiva RS, São Clemente SC, Rodrigues AE, Peralta ASL, Matos ER. Cestóides Trypanorhyncha parasitos de Sciaenideos de importância comercial, capturados no Litoral Amazônico, Brasil. Rev Bras Cienc Vet 2011; 18(1): 3-5.

Eiras JC, Takemoto RM, Pavanelli GC. Diversidade de parasitos de água doce do Brasil. Maringá: Clichetec; 2010.

Fagerholm HP. Systematic implications of male caudal morphology in ascaridoid nematode parasites. Syst Parasitol 1991; 19(3): 215-229. http:// dx.doi.org/10.1007/BF00011888.

Felizardo NN, Knoff M, Pinto RM, Gomes DC. Larval anisakid nematodes of the flounder Paralichthys isosceles Jordan, 1890 (Pisces: Teleostei) from Brazil. Neotrop Helminthol 2009; 3(2): 57-64.

Ferreira EJG, Zuanon JAS, Santos GM. Peixes comerciais do médio Amazonas: região de Santarém, Pará. Brasília: Edições IBAMA; 1998.

Fontenelle G, Knoff M, Felizardo NN, Lopes LMS, São Clemente SC. Nematodes of zoonotic importance in Cynoscion guatucupa (Pisces) in the State of Rio de Janeiro. Rev Bras Parasitol Vet 2013; 22(2): 281-284. http://dx.doi.org/10.1590/S1984-2961201300 5000019.

Iñiguez AM, Carvalho VL, Motta MRA, Pinheiro DCSN, Vicente ACP. Genetic analysis of Anisakis typica (Nematoda: Anisakidae) from cetaceans of the northeast coast of Brazil: New data on its definitive hosts. Vet Parasitol 2011; 178(3-4): 293-299. http://dx.doi.org/10.1016/j. vetpar.2011.01.001. PMid:21324600.

Ińiguez AM, Santos CP, Vicente ACP. Genetic characterization of Anisakis typica and Anisakis physeteris from marine mammals and fish from the Atlantic Ocean off Brazil. Vet Parasitol 2009; 165(3-4): 350-356. http:// dx.doi.org/10.1016/j.vetpar.2009.07.012. PMid:19651475.

Klimpel S, Palm HW. Anisakid nematode (Ascaridoidea) life cycles and distribution: increasing zoonotic potential in the time of climate change?
In: Mehlhorn H. Progress in parasitology, parasitology research monographs 2. Berlin: Springer Berlin Heidelberg; 2011. p. 201-222.

Knoff M, Gomes DC. Metodologia básica para coleta e processamento de helmintos parasitos. In: Molinaro EM, Caputo LFG, Amendoeira MRR. Conceitos e métodos para formação de profissionais em laboratórios de saúde. Rio de Janeiro: EPSJV; 2012. p. 251-281. v. 5.

Knoff M, São Clemente SC, Fonseca MCG, Felizardo NN, Lima FC, Pinto RM, et al. Anisakidae nematodes in the blackfin goosefish, Lophius gastrophysus Miranda-Ribeiro, 1915 purchased in the State of Rio de Janeiro, Brazil. Acta Sci Biol Sci 2013; 35(1): 129-133. http://dx.doi. org/10.4025/actascibiolsci.v35i1.12185.

Lopes Torres EJ, Souza W, Miranda K. Comparative analysis of Trichuris muris surface using conventional, low vacuum, environmental and field emission scanning electron microscopy. Vet Parasitol 2013; 196(3-4): 409416. http://dx.doi.org/10.1016/j.vetpar.2013.02.026. PMid:23537947.

Martins ML, Fujimoto RY, Moraes FR, Andrade PM, Nascimento AA, Malheiros EB. Description and prevalence of Thynnascaris sp. larvae Dollfus, 1933 (Nematoda: Anisakidae) in Plagioscion squamosissimus Heckel, 1840 from Volta Grande Reservoir, state of Minas Gerais, Brazil. Rev Bras Biol 2000; 60(3): 519-526. http://dx.doi.org/10.1590/S003471082000000300017 . PMid:11188878.

Melo FTV, Rodrigues RAR, Giese EG, Gardner SL, Santos JN. Histopathologic aspects in Plagioscion squamosissimus (HECKEL, 1940) induced by Neoechinorhynchus veropesoi, metacestodes and anisakidae juveniles. Rev Bras Parasitol Vet 2014; 23(2): 224-230. http://dx.doi. org/10.1590/S1984-29612014048. PMid:25054502.

Motta MRA, Pinheiro DCSN, Carvalho VL, Viana DA, Vicente ACP, Iñiguez AM. Gastric lesions associated with the presence of Anisakis spp. Dujardin, 1845 (Nematoda: Anisakidae) in cetaceans stranded on the coast of Ceará, Brazil. Biota Neotrop 2008; 8(2): 91-95. http://dx.doi. org/10.1590/S1676-06032008000200010.

Rodrigues MV, Pantoja JCF, Guimarães CDO, Benigno RNM, Palha MDC, Biondi GF. Prevalence for nematodes of hygiene-sanitary importance in fish from Colares Island and Vigia, Pará, Brazil. Rev Bras Cienc Vet 2015; 22(2): 124-128. http://dx.doi.org/10.4322/rbcv.2015.364.

Santos CP, Lodi L. Occurrence of Anisakis physeteris Baylis, 1923 and Pseudoterranova sp. (Nematoda) in pygmy sperm whale Kogia breviceps (De Blaivillei, 1838) (Physeteridae) in northeastern coast of Brazil. Mem Inst Oswaldo Cruz 1998; 93(2): 187-188. http://dx.doi.org/10.1590/ S0074-02761998000200009. PMid:9698890.

Santos CP, Rohde K, Ramos R, Di Beneditto AP, Capistrano L. Helminths of cetaceans on the southeastern coast of Brazil. J Helminthol Soc Wash 1996; 63(1): 149-152.

Spalding MD, Fox HE, Allen GR, Davidson N, Ferdaña ZA, Finlayson $\mathrm{M}$, et al. Marine ecoregions of the world: a bioregionalization of coastal and shelf areas. Bioscience 2007; 57(7): 573-583. http://dx.doi. org/10.1641/B570707

Tavares LER, Saad CDR, Cepeda PB, Luque JL. Larvals of Terranova sp. (Nematoda: Anisakidae) parasitic in Plagioscion squamosissimus (Perciformes: Sciaenidae) from Araguaia river, State of Tocantins, Brazil. Rev Bras Parasitol Vet 2007; 16(2): 110-115. PMid:17706015.

Zerbini AN, Santos MCO. First record of the pygmy killer whale Feresa attenuata (Gray, 1874) for the Brazilian coast. Aquat Mamm 1997; 23(2): 105-109. 